\title{
The Impact of Access to Finance and Environmental Factors on Entrepreneurial Intention: The Mediator Role of Entrepreneurial Behavioural Control
}

\author{
Thu Thuy Nguyen
}

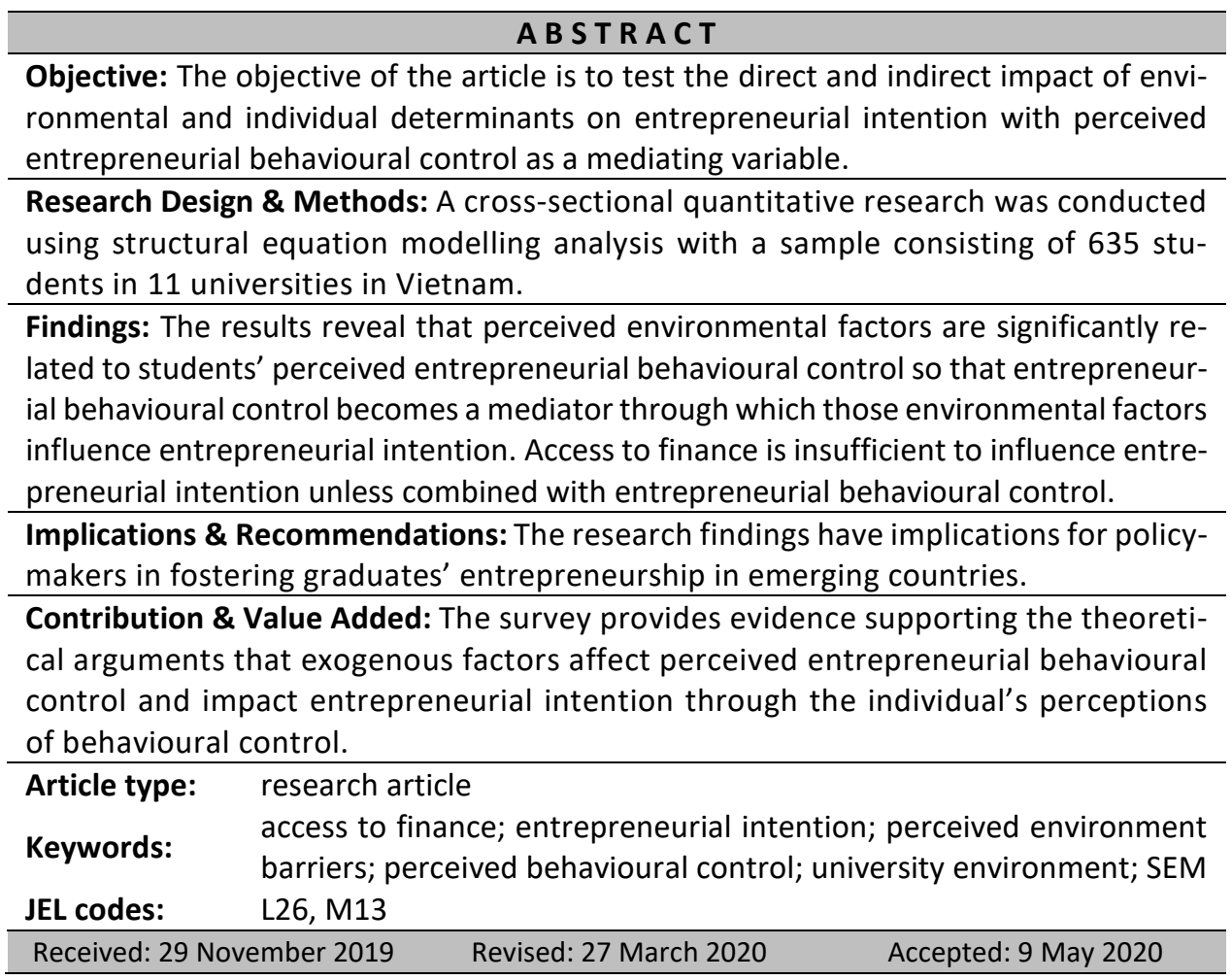

Suggested citation:

Nguyen, T.T. (2020). The Impact of Access to Finance and Environmental Factors on Entrepreneurial Intention: The Mediator Role of Entrepreneurial Behavioural Control. Entrepreneurial Business and Economics Review, 8(2), 127-140. https://doi.org/10.15678/EBER.2020.080207 


\section{INTRODUCTION}

Entrepreneurship has recently been recognised as the critical driving force of economic development and national prosperity (Khan, 2013). The governments of many countries view small and medium-sized enterprise development as the key success factor in their country's strategy toward economic growth and job creation (Lim, Morse, Mitchell, \& Seawright, 2010). Entrepreneurship promotion is an important component in that strategy. Since then, fostering entrepreneurship has become a topic of the highest priority in economics and management (Bae, Miao, \& Fiet, 2014). Since scholars with a cognitive approach argue that entrepreneurial intention plays a significant role in the decision to start a new business, recent studies in entrepreneurship place increasing emphasis on the entrepreneurial intention of university students on the basis that younger people are more willing to be entrepreneurs (Florin \& Rossiter, 2007).

Despite the widespread discussion of entrepreneurial intention in the literature, very few studies integrate the impact of individual and environment perspectives on entrepreneurial intention in single framework (Clercq, Lim, \& Oh, 2011). Previous studies focus on contextual factors and intention-based models, which indicate that entrepreneurship is not the result of individual and external factors in separation (Dolce, Molino, \& Ghislieri, 2018). Entrepreneurship cannot be explained solely by characteristics of certain people without making reference to the ecosystem in which they operate (Gnyawali \& Fogel, 1994). A comprehensive model consisting of both individual and institutional perspectives should be suggested to more accurately explain entrepreneurial intention (Clercq et al., 2011). Fayolle and Liñán (2014) suggest the further examination of the combined impact of individual and structural context on entrepreneurship. The current study will examine the impact of such variables as the access to finance as an individual factor and two external environment factors such as university environment, and environment barriers - on the entrepreneurial intention of university students, neglected in the entrepreneurial literature.

Moreover, prior studies document the impact of environment and personal factors on entrepreneurs' cognition of behavioural control and intention. However, findings on the impact of access to finance, university environment, and environmental barriers on college students' entrepreneurial intentions are inconsistent in the literature. A positive relationship between perceived university environment and students' entrepreneurial intention appears in Turker and Selcuk (2009) and Lüthje and Franke (2003), while Sesen (2013), Yurtkorua, Kuşcub, and Doğanayc (2014) find no significant relationship. Schwarz, Wdowiak, Jarz, and Breitenecker (2009); Hadjimanolis (2016); Shahid, Imran, and Shehryar (2017) find that entrepreneurial environment does not affect students' entrepreneurial intentions, while Lüthje and Franke (2003) find that the relationship between entrepreneurial environment barriers and students' entrepreneurial intentions is significant. The inconsistent evidences on the relationship between those factors and students' entrepreneurial intention reinforce the need for a deeper examination of the case, particularly in other contexts or with a mediator (Clercq et al., 2011; Yurtkorua et al., 2014).

In this research, I choose to focus on perceived entrepreneurial behavioural control as a mediator of the relationship among finance, university environment, environment barriers, and entrepreneurial intention. Perceived entrepreneurial behavioural control is predictor of intention (Ajzen, 1991); and perceived behavioural control plays an important role in 
career development (Krueger, Reilly, \& Carsrud, 2000). Although perceived entrepreneurial behavioural control is used as mediator in several intention studies - e.g. by Dolce et al. (2018) and Yurtkorua (2014) - this is the first empirical article to examine perceived entrepreneurial behavioural control as the mediator of relationship among access to finance, university environment, and environment barriers with entrepreneurial intention.

This empirical study's main objective is to test the direct relationship among the three proposed determinants - entrepreneurial environment barriers, access to finance, university environment - and entrepreneurial intention. Moreover, we test the indirect impact of the above factors on entrepreneurial intention with perceived entrepreneurial behavioural control as the mediator, which for now has been a gap in the literature. This study contributes to entrepreneurial literature in two ways. Firstly, while previous studies only focus on the direct effect of entrepreneurial environmental factors on entrepreneurial intention, this research investigates the mediating effect of entrepreneurially perceived behavioural control in the relationship between entrepreneurial environmental factors and entrepreneurial intention by using structural equation modelling analysis. Secondly, this study contributes to entrepreneurial literature by applying the entrepreneurship contextual theory and planned behavioural theory to the emerging context of Vietnam.

This article consists of four parts: literature review, methodology, discussion of results, and conclusion.

\section{LITURATURE REVIEW}

\section{Entrepreneurial Behavioural Control and Intention}

There are several approaches in the field of entrepreneurship research. Numerous studies investigate individual differences as determinants of entrepreneurial behaviours. Since this approach yields ambiguous results, the cognitive approach with the planned behaviour theory or intention base model received considerable interests (Krueger et al., 2000). The theory of planned behaviour (TPB) states that entrepreneurship is a planned, intentional behaviour. Entrepreneurial intention is a reliable and best predictor of entrepreneurial behaviours and activities (Ajzen, 1991). Entrepreneurial intention is the internal driving force that leads individuals to seize opportunities and implement entrepreneurial actions (Cha \& Bae, 2010). Therefore, study of entrepreneurial intention offers us a chance to understand and predict entrepreneurial activity (Linan \& Chen, 2009).

According to the TPB proposed by Ajzen (1991), entrepreneurial intention is a conviction self-acknowledged by the individual that $s /$ he intends to set up a new business venture and consciously plans to do so at some point in the future.

Perceived behavioural control is someone's perception of the ease or difficulty of performing a behaviour (Ajzen, 1991). Perceived behavioural control indicates an individual's feel of how easily it would be to implement entrepreneurial activities. Perceived behavioural control bases on the evaluation of one's controllability of the process of developing a new venture. This concept is not the same but very similar to perceived feasibility or selfefficacy concepts, as all of them reflect the personal judgment of an individual about own ability to perform a behaviour (Krueger et al., 2000).

The TPB assumes that perceived behavioural control is the proximal predictor of intention. Perceived behavioural control precedes the formation of entrepreneurial inten- 
tion, then precedes entrepreneurial behaviour (Ajzen, 1991). The impact of perceived entrepreneurial behavioural control on entrepreneurial intention is widely confirmed in the literature and tested in empirical studies that apply the TPB (Liñán \& Chen, 2009; Yurtkorua, 2014; Wach \& Wojciechowski, 2016).

H1: Perceived entrepreneurial behavioural control is positively related to entrepreneurial intention.

\section{Access to Finance versus Perceived Behavioural Control and Intention}

Entrepreneurial intention is influenced by multiple factors including individual factors such as people's resources and characteristics (Clercq et al., 2011). Potential entrepreneurs gather capital from various sources as they hardly manage to finance a new venture only by themselves (Smith \& Beasle, 2011). The capital needed to start a new business can be obtained from personal savings, loans from friends, family or extended family networks, credit systems, or through sharing partnership with outside investors and venture funds (Urban \& Ratsimanetrimanana, 2019). In developing countries, informal sources of loans with high interest rates from black financial market substantially contribute to business start-ups (Kwong \& Evans, 2012).

The perception of access to finance is defined as an assessment of the individual's ability to effectively find, access, and utilise capital (Pham, 2019). Access to finance is crucial for every subsequent entrepreneurial activities (Kristiansen \& Indarti, 2004). A considerable number of people gave up on their intention of nascent entrepreneurial careers because of the inability to gather finance capital (Sesen, 2013). Blanchflower and Oswald (1990) indicate that if governments want to foster entrepreneurship, they need to generate various financial sources and make it accessible to potential entrepreneurs (Kwong \& Evans, 2012). Some empirical studies show that the lack of access to finance and difficulties in reimbursing loans in the official financial system is more a major barrier among entrepreneurs in developing countries than in developed countries with effective financial infrastructure (Kristiansen \& Indarti, 2004). Access to finance is a typical obstacle to startups, especially in countries with weak credit and limited venture capital institutions.

Clercq et al. (2011) and Urban and Ratsimanetrimanana (2019) indicate that individuals with access to financial capital are more likely to become entrepreneurs. Finance is probably the most supportive trigger event of entrepreneurial intention (Schwarz et al., 2009). Thus:

H2: Perceived access to finance is positively related to entrepreneurial intention.

Previous studies show that individuals with high opportunities to access to financial capital are more confident about becoming entrepreneurs, because entrepreneurs confront various challenges during their efforts to deal with high levels of uncertainty in new business creation process. Research of Pham (2019) finds a positive relationship between access to finance and the perception of entrepreneurial behavioural control in social entrepreneurs. Several empirical studies conclude that the main hindrances to business innovation and success of potential entrepreneurs in developing countries are the lack of access to credit schemes and the constraints of financial systems. The lack of access to finance is a major obstruction that hinder entrepreneurs' self-efficacy (Kristiansen \& Indarti, 2004).

H3: Access to finance is positively related to perceived entrepreneurial behavioural control. 


\section{Environment Barriers with Perceived Behavioural Control and Intention}

Entrepreneurship process is a complex phenomenon and is impacted by numerous actors in the entrepreneurship environment (Khan, 2013). Sociological theories emphasise that entrepreneurship is a process involving economic, social, and cultural contexts. Entrepreneurship cannot be fully understood without reference to the institutional and socio-cultural context in which it arises, develops, and operates (Lim et al., 2010). Gnyawali and Fogel (1994) note that there are both supporting and hindering factors in entrepreneurial environment. Schwarz et al. (2009) treat "environment barriers" as an important factor in the model of students' entrepreneurial intentions.

Environment barriers are discussed by several studies. Lüthje and Frank (2003) suggest that individuals are less inclined towards entrepreneurship in environments that disapprove of their choices; and environment barriers can also ruin optimism and may even convert students originally interested in an entrepreneurship career into graduates who seek a career in established large companies. A student may not intend to start his own business due to the negative perception of entrepreneurial environment. Fini, Meoli, Sobrero, Ghiselli, and Ferrante (2016) emphasise that perceived environmental barriers influence entrepreneurial intention; these barriers may emerge from characteristics of local context (competition, availability of logistic infrastructure, market entry barrier) and government policies (support programs, legal frameworks). In developing countries, business informality is considered to be a considerable barrier in the entrepreneurship environment. Informality causes the lack of information, unfair competition, and those barriers appear are obstacles for entrepreneurial intention (Robertson, Collins, Medeira, \& Slater, 2003). Franke and Lüthje (2004), Schwarz et al. (2009) also develop a model that considers contextual barriers as directly affecting entrepreneurial intentions.

H4: Environment barriers are positively related to entrepreneurial intentions.

Recently, most entrepreneurship studies assume that a business mindset is transferred in education and human thinking can be shaped by the surrounding environments. Entrepreneurial event theory states that life path changes impact individual perceptions of feasibility (Krueger et al., 2000). Therefore, the perception of behavioural control is proposed to be probably dependent on the individual perception of immediate environment. Student might believe they are incompetent to set up a business, regardless of their comparatively good attitude towards entrepreneurship, because they perceive the environmental conditions as very unfavourable. Krueger et al. (2000) indicate that the environment factor is an adjustable variable, which directly impacts the perception of behavioural control, as graduates with negative a perception of barriers in the environment may believe they are incapable to be an entrepreneur.

H5: Environment barriers are positively related to the perception of behavioural control. 


\section{University Support Environment and Entrepreneurship-Perceived Behavioural Control and Intention}

Researchers find that innovative and creative entrepreneurial universities environment like the Massachusetts Institute of Technology (MIT), Harvard University, or Stanford University successfully foster entrepreneurial activities. A remarkable number of start-ups was founded by graduates of selected US business schools, while there is a limited number from other universities, this fact raises the question of whether university environments impact entrepreneurship (Lüthje \& Franke, 2003). Although some researchers have argued that entrepreneurship is an innate behaviour, many others believe it is an attitude that can be learned (Bae et al., 2014). The impact of university environment on the creation of future entrepreneurs is broadly discussed in the literature. Turker and Selcuk (2009) and Schwarz et al. (2009) propose that students who perceive university environment as supportive of entrepreneurship likely have stronger entrepreneurial intentions. In terms of the general university context, the presence of an entrepreneurship supportive environment and the positive image of entrepreneurs within educational institutions encourage student intention to start a new business (Shahid et al., 2017).

H6: University entrepreneurial environment is positively related to entrepreneurial intention.

The influence of the university environment on self-efficacy (feasibility) necessary to become an entrepreneur is considered by a few studies in the entrepreneurship literature (Guerrero \& Urbano, 2015). Although Fayolle (2006) fails to evidence the impact, the research of Guerrero and Urbano (2015) recognises the existence of a direct, positive, and significant relationship between university environment conditions and entrepreneurship self-efficacy. Thus,

H7: University entrepreneurial environment is positively related to perceived entrepreneurial behavioural control.

\section{The Mediator Role}

In the TPB model, exogenous factors indirectly influence intention through personal-situation perceptions of perceived behavioural control (Ajzen, 1991). Lüthje and Franke (2003) stipulate that perceived behavioural control is a determinant of entrepreneurial intention, and the perception of behavioural control is in fact a product of combined effects of several other exogenous variables such as personal, demographical, and external elements. Accordingly, I propose the next three hypotheses of the mediator role:

H8a: The perception of behavioural control mediates the relationship between access to finance and entrepreneurial intention.

H8b: The perception of behavioural control mediates the relationship between environment barriers and entrepreneurial intention.

H8c: The perception of behavioural control mediates the relationship between university entrepreneurial environment and entrepreneurial intention. 


\section{MATERIAL AND METHODS}

This empirical study seeks to quantitatively test the model of the relationships between selected environment and individual factors and the perception of entrepreneurial behavioural control and intention. Before quantitative research, I implemented an additional exploratory qualitative study with five in-depth interviews to check, confirm, and revise the theoretical model and scales. After the exploratory study, I conducted the official quantitative study with a questionnaire table.

All measures are borrowed from previous studies (Table 1). All use five-point Likert scales. Surveys were administered to final year undergraduate college students in two academic majors, engineering and economics-business, at 11 universities in Hanoi, Vietnam. Questionnaires were randomly distributed to target respondents with control of sex, major, and universities.

Statistical analysis was conducted with the SPSS 22.0 and the AMOS 22.0 software. First, Cronbach's alpha, explorative factor analysis (EFA), confirmatory factor analysis (CFA) were implemented to assess the validity and reliability of variables. Second, the structural equation modelling (SEM) was applied to estimate path coefficients for proposed relationships (Hair, Black, Anderson, \& Babin, 2009). In order to investigate mediating impacts of factors on entrepreneurial intention, I applied the bootstrapping method, because it is more effective than Sobel test if using original data (Preacher \& Hayes, 2008).

Total responses consisted of 638 questionnaires, in which $62.7 \%$ are men and $37,3 \%$ are women. $18 \%$ of sample respondents create a business or invest in a new business; $82 \%$ do not have entrepreneurship experiences. $36.4 \%$ of respondents have parents with business related jobs; $63.6 \%$ of students' parents are doing other careers. $55.8 \%$ of sample respondents study business and economics major.

\section{RESULTS AND DISCUSSION}

\section{Measures Assessment}

To test the reliability of scales, I conducted Cronbach's Alpha analysis. All scales showed Cronbach's Alpha from 0.776 to 0.850 . All the research variables have "Cronbach's Alpha if item deleted" of each item are lower than a scale's Cronbach's Alpha. All the value of "Corrected item total correlation" of individual items are bigger than 0.3 (Table 1 ).

To test the validity of the study's instrument, EFA analysis was done at the same time for five variables, including independent and dependent variables with 24 items using promax rotation method. All items loaded in original factors with factor loading in all cases above 0.5; initial Eigenvalues $=60.921>50 \%$; KMO $=0.887$; Sig. (Bartlett's Test) $=0.000$. The validity of measurement instruments is confirmed.

Then, the confirmatory factor analysis (CFA) was performed with survey data. The measurement models exhibited a reasonably good level of fit: $\chi 2=482.244$, $\mathrm{df}=241, \mathrm{p}=0.000<0.5 ; \chi 2 / \mathrm{df}=2.001<3 ; \mathrm{GFI}=0.939, \mathrm{CFI}=0.960, \mathrm{TLI}=0.954>0.9$, RMSEA = 0.040; standardised regression weights of all items are higher than 0.5 (Hair et al., 2009). Thus, validity is proven for all scales, as all scales are internally consistent and reliable for using in next steps. 
Table 1. Measures

\begin{tabular}{|l|c|c|c|c|}
\hline \multicolumn{1}{|c|}{ Variables } & $\begin{array}{c}\text { Number of } \\
\text { items }\end{array}$ & Code & Sources & $\begin{array}{c}\text { Cronbach's } \\
\text { alpha }\end{array}$ \\
\hline Entrepreneurial intention & 6 & EI & Linan and Chen (2009) & 0.847 \\
\hline Access to finance & 3 & FS & Sesen (2013) & 0.776 \\
\hline $\begin{array}{l}\text { Entrepreneurial environment } \\
\text { barriers }\end{array}$ & 6 & EB & Franke and Lüthje (2004) & 0.827 \\
\hline $\begin{array}{l}\text { Entrepreneurship university } \\
\text { environment }\end{array}$ & 3 & UE & Schwarz et al. (2009) & 0.828 \\
\hline $\begin{array}{l}\text { Perceived entrepreneurial } \\
\text { behavioural control }\end{array}$ & 6 & PBC & Linan and Chen (2009) & 0.850 \\
\hline
\end{tabular}

Source: own study.

\section{The Result of Hypothesis Testing}

Goodness-of-Fit indicators show the overall compatibility of the model. The model meets the required Goodness-of-Fit criteria. The overall fit statistics of the model illustrate an acceptable level of good fit: $\chi 2=562.149, \mathrm{df}=242, \mathrm{p}=0.000<0.05 ; \mathrm{CMIN} / \mathrm{df}=2.323<0.3$, $\mathrm{CFI}=0.947, \mathrm{GFI}=0.930, \mathrm{TLI}=0.940>0.9, \mathrm{RMSEA}=0.046$ (Hair et al., 2009). Therefore, the design of the model is compatible with the sample data, as the original model is used to test the relationship between variables.

Table 2. Regression Weights

\begin{tabular}{|c|c|c|c|c|c|c|c|c|}
\hline \multicolumn{4}{|c|}{ Hypothesis } & Estimate & S.E. & C.R. & $\mathbf{P}$ & Description \\
\hline H5: & PBC & $<--$ & EB & -0.123 & 0.041 & -3.008 & 0.003 & Supported \\
\hline H7: & PBC & $<--$ & UE & 0.256 & 0.042 & 6.115 & $* * *$ & Supported \\
\hline H3: & PBC & $<--$ & FS & 0.201 & 0.048 & 4.155 & $* * *$ & Supported \\
\hline H2: & $\mathrm{EI}$ & $<--$ & FS & 0.089 & 0.059 & 1.509 & 0.131 & Not Supported \\
\hline H6: & El & $<--$ & UE & 0.130 & 0.052 & 2.496 & 0.013 & Supported \\
\hline H4: & $\mathrm{EI}$ & $<---$ & EB & -0.109 & 0.050 & -2.180 & 0.029 & Supported \\
\hline H1: & $\mathrm{EI}$ & $<--$ & PBC & 0.649 & 0.067 & 9.666 & $* * *$ & Supported \\
\hline
\end{tabular}

Source: own study.

A total of seven direct relationships were tested. Six out of seven hypotheses are statistically significant, and only one is not significantly supported by the research data (Table 2).

The hypotheses test shows that the relationship between entrepreneurial perceived behavioural control and entrepreneurial intention is very strong $(\beta=0.649$; sig. $<0.001)$. This result is consistent with the theoretical establishment of TPB intention model and previous studies based on the TPB model (Linan \& Chen, 2009; Yurtkorua, 2014; Wach \& Wojciechowski, 2016). Moreover, the result proves the argument of Sesen (2012) that there is a strong influence in developing economies of perceived control on the intention to be an entrepreneur. Perceived behavioural control is a critical factor in predicting entrepreneurial intention. Students who are more convinced that a start-up is not a difficult task are more inclined to create a new venture (Brice et al., 2007). This result also supports cognitive theory and Ajzen's TPB model (1997). The TPB can be seen as a detailed and decisive instrument for examining and identifying the factors and relations that motivate 
entrepreneurship at the university. This agrees with the recommendations of Brice and Spencer (2007) that one of the key elements of entrepreneurship process is forming the beliefs regarding the chances to succeed in a given venture.

Entrepreneurship university environment directly effects in the positive and significant correlation on entrepreneurial intention $(\beta=0.130$; sig. $<0.05)$. This analysis of effect is consistent with the studies conducted by Turker and Selcuk (2009), Schwarz et al. (2009), and Shahid et al. (2017), which affirm that socially supportive environment in universities predicts entrepreneurial intention. While entrepreneurship education alone does not significantly influence entrepreneurial intention - as indicated in two studies by Yurtkorua et al. $(2014 ; 2014)$ - what is really important is the entrepreneurial environment at universities. This study emphasises the role of a supportive university environment by providing not only entrepreneurship education courses but also encouragement, inspiration, role models, and a creative and innovative atmosphere to develop students' entrepreneurial intention.

Moreover, an entrepreneurial university environment has a positive significant correlation with perceived entrepreneurial behavioural control $(\beta=0.256$; sig. $<0.001)$. The analysis of effect is supported by the study conducted by Guerrero and Urbano (2015), who find that educational factors in university environment are significantly associated with key beliefs of entrepreneurship-perceived behavioural control. This is consistent with a recent argument of management scholars that business behaviours are learned and that the human mind is a blank slate that can be shaped by schools and education (Bae et al., 2014). This is supportive for the proposal of Verzat and Bachelet (2006) that entrepreneurship can be taught and learned, as educational determinants can help students deal with business complexity and the development of capacities particularly important for classes of young, not to mention undergraduate students who have no or very limited business experience.

The entrepreneurial environment barriers negatively influence entrepreneurial intention $(\beta=-0.109 ;$ sig. $<0.05)$. This agrees with the evidence obtained by previous studies (Lüthje \& Franke, 2003; Benhabib et at., 2014). The results confirm the existence of a direct and significant relationship between the environment and entrepreneurial intention, which supports the claim of Gnyawali and Fogel (1994) that it is insufficient and incomplete to disregard environment in an entrepreneurship study. Limitations in entrepreneurship environment and the lack of an effective support scheme discourage students from developing entrepreneurial intentions.

The next hypothesis test confirmed that entrepreneurial environment barriers had negative and significant correlation with perceived entrepreneurial behavioural control $(\beta=-0.123$; sig. $<0.005)$. This supports the argument of the Shapero Model of entrepreneurial event that a socially unsupportive institutional environment deters or prevents potential entrepreneurs to access important resources to create their businesses, which has a negative motivating effect and also unconsolidated nascent entrepreneurs' self- believe of behavioural control (Krueger et al., 2000).

The current study disagrees with previous studies of Clercq et al. (2011), Urban, and Ratsimanetrimanana (2019), who find that access to financial capital increased the intention to start a new venture, as the direct effect of access to finance on entrepreneurial intention in this research is positive but insignificant (sig. $>0.05$ ). However, the result confirms the direct, positive, and significant correlation effects of perceived access to finance 
on entrepreneurial behavioural control $(\beta=0.201$; sig. $<0.001)$. Thus, in contrast to developed countries, the developing context of Vietnam economy shows that access to finance does not directly associate with a business start-up intention. The result again proves the findings of Pham (2019) about social entrepreneurs, which were conducted in Vietnam. A possible explanation about the difference is that individuals in other contexts may raise their start-up capital from borrowing from formal institutions, which they may have difficulty accessing, because entrepreneurs typically lack reliable performance data, collateral, and legitimacy, thus making it difficult for them to secure financing from external sources (Urban \& Ratsimanetrimanana, 2019). With the current Vietnam government's campaign to foster entrepreneurship, students receive many financial opportunities offered by country programs and venture funds. Another reason for the difference is that students relatively lack the experience of securing financing and establishing a business, so they may be optimistic about their capital access capabilities, as proposed by Sesen (2013). Therefore, other barriers in environments (e.g. competition or business opportunities) may be more important for students than financial issues when considering future entrepreneurship careers. Further studies are needed to properly assess this hypothesis.

Table 3. Indirect effects using bootstrapping (2000 replications): unstandardised coefficients

\begin{tabular}{|c|c|c|c|c|}
\hline Indirect effects & Est. & S.E. & $\mathbf{p}$ & Cl 95\% (lower and upper bounds) \\
\hline EB-PBC-EI & -0.080 & -0.071 & 0.009 & $(-0.154,-0.018)$ \\
\hline UE-PBC-EI & 0.166 & 0.155 & 0.001 & $(0.102,0.242)$ \\
\hline FS-PBC-EI & 0.131 & 0.118 & 0.001 & $(0.058,0.233)$ \\
\hline
\end{tabular}

Source: own study.

In order to investigate the indirect effect of factors on entrepreneurial intention with the mediator role of perceived behavioural control, we apply the bootstrapping method (Tables 3 and 4). The result shows that although finance do not directly influence entrepreneurial intention, it plays a significant role in building perceived behavioural control ( $\beta$ indirect 0.131 , sig. 0.01). The result is similar with the study by Pham (2019) on social entrepreneurship in Vietnam and by Kristiansen and Indarti (2004). The results confirmed that entrepreneurship university environment and entrepreneurial environment barriers have both significant indirect and direct effect on entrepreneurial intention (Table 4). This evidence supports the theoretical argument of Lim et al. (2010). Thus, hypotheses $\mathrm{H} 8 \mathrm{a}, \mathrm{H} 8 \mathrm{~b}, \mathrm{H} 8 \mathrm{c}$ are supported by the research data.

Table 4. Total, direct, and indirect effects: unstandardised coefficients

\begin{tabular}{|l|l|c|c|c|c|c|}
\hline \multicolumn{1}{|c|}{ Total, direct and indirect effects } & FS & UE & EB & PBC & EI \\
\hline Total effect & PBC & 0.201 & 0.256 & -0.123 & 0.000 & 0.000 \\
\hline & EI & 0.220 & 0.296 & -0.189 & $\underline{0.649}$ & 0.000 \\
\hline Direct & PBC & 0.201 & 0.256 & -0.123 & 0.000 & 0.000 \\
\hline & EI & 0.089 & 0.130 & -0.109 & 0.649 & 0.000 \\
\hline Indirect & PBC & 0.000 & 0.000 & 0.000 & 0.000 & $\underline{0.000}$ \\
\hline & EI & 0.131 & 0.166 & -0.080 & 0.000 & 0.000 \\
\hline
\end{tabular}

Source: own study. 
The results confer the assumption of Krueger et al. (2000) in entrepreneurial intention model, which posits that exogenous factors - environmental or personal - influence individual intention through perceived behavioural control.

\section{CONCLUSIONS}

The survey provides evidence supporting theoretical arguments that perceived contextual barriers, supportive entrepreneurship university environment, and individual perceived access to finance play significant roles in the development of entrepreneurial perceived behavioural control and the intention of university students. Previous studies show that entrepreneurial intention could be influenced by environment but they do not clarify the role of entrepreneurial perceived behavioural control. We understand the case better now. The entrepreneurial perceived behavioural control is important if we want to influence entrepreneurial intention, because it mediates the relationship between environment factors and access to finance with intention.

This knowledge is important for policy-makers and universities in designing entrepreneurship support scheme in a more targeted and effective manner. Firstly, encouraging students' entrepreneurial intention should be done not only in universities but also in a whole society and in communities. Secondly, public policy should intensify activities to remove obstacles in government regulations, the availability of qualified new venture consultants, the level of competition, and general support infrastructure. The design of intervention should not only focus on factors that could change intentions but also obstacles that are antecedents of actual behavioural control, such as access to finance.

This research has limitations. Firstly, this cross-sectional study limits us to seeing changes in perceived behavioural control and intention over time. Longitudinal studies are better for understanding the process of becoming new entrepreneurs. Future studies should scrutinise the relationship between environment, entrepreneurship-perceived behavioural control, intention, and entrepreneurship behaviours; in process, actions can occur after much time passes. Secondly, this study only focuses on three major factors without considering other supportive factors, such as government and university policies, facilities, or education methods. Entrepreneurial intention may be influenced by a myriad of factors, including individual psychological traits and other environmental attributes. A comprehensive model of various factors might have a better explanation for the case. This study recommends more research using other mediating or moderating variables in order to better explain the variation in the influence of environmental factors on students' entrepreneurial intention.

\section{REFERENCES}

Ajzen, I. (1991). The theory of planned behavior. Organizational Behavior and Human Decision Processes, 50(2), 179-211.

Bae, T.J., Qian, S., Miao, C., \& Fiet, J.O. (2014). The Relationship between Entrepreneurship Education and Entrepreneurial Intentions: A Meta-Analytic Review. Entrepreneurship Theory and Practice, 38(2), 217-254. 
Benhabib, A., Merabet, A., Benachenhou, M., Grari, Y., Boudia, F., \& Merabet, H. (2014). Environmental and Individual Determinants of Female Entrepreneurship in Algeria: Applying the Structural Equation Modeling. Entrepreneurial Business and Economics Review, 2(1), 65-80.

Brice, J., \& Spencer, B. (2007). Entrepreneurial profiling: A decision policy analysis of the influence of entrepreneurial self-efficacy on entrepreneurial intent. Academy of Entrepreneurship Journal, 13(2), 47-67.

Cha, M., \& Bae, Z. (2010). The entrepreneurial journey: From entrepreneurial intent to opportunity realization. Journal of High Technology Management Research, 21(1), 31-42

Clercq, D.D., Lim, D.S.K., \& Oh, C.H. (2011). Individual-Level Resources and New Business Activity: The Contingent Role of Institutional Context. Entrepreneurship Theory and Practice, 37(2), 303-330.

Dolce, V., Molino, M., Cortese, C.G., \& Ghislieri, C. (2018). Personality and social support as determinants of entrepreneurial intention. Gender differences in Italy. PLOS ONE, 13(6), 1-19.

Fayolle, A., \& Liñán, F. (2014). The future of research on entrepreneurial intentions. Journal of Business Research. Elsevier, 67(5), 663-666.

Fini, R., Meoli, A., Sobrero, M., Ghiselli, S., \& Ferrante, F. (2016). Student Entrepreneurship: Demographics, Competences and Obstacles. Technical Report - Almalaurea Consortium, February 2016, 1-35.

Florin, J., Karri, R., \& Rossiter, N. (2007). Forstering entrepreneurial drive in business education: an attitudinal approach. Journal of Management Education, 31(1), 17-42.

Franke, N., \& Lüthje, C. (2004). Entrepreneurial intentions of business students: a benchmarking study. International Journal of Innovation and Technology Management, 1(3), 269-288.

Gnyawali, D., \& Fogel, D. (1994). Environments for entrepreneurship development: key dimensions and research implications. Entrepreneurship Theory and Practice, 18(4), 43-62.

Guerrero, M., \& Urbano, D. (2015). The effect of university and social environments on graduates' start-up intentions: an exploratory study in Iberoamerica. In R. Blackburn, U. Hytti, \& F. Welter (Eds), Context, Process and Gender in Entrepreneurship: Frontiers in European Entrepreneurship Research (pp. 55-86). Northampton, MA: Edward Elgar Publishing.

Hadjimanolis, A. (2016). Perceptions of the institutional environment and entrepreneurial intentions in a small peripheral country. International Journal of Entrepreneurship and Small Business, 28(1), 20-35.

Hair, J.F.J., Black, W.C., Anderson, R.E., \& Babin, B.J. (2009). Multivariate Data Analysis. Essex: Pearson Education Limited.

Khan, M.R. (2013). Mapping entrepreneurship ecosystem of Saudi Arabia. World Journal of Entrepreneurship, Management and Sustainable Development, 9(1), 28-54.

Kristiansen, S., \& Indarti, N. (2004). Entrepreneurship intentions among Indonesian and Norwegian students. Journal of Enterprising Culture, 12(1), 55-78.

Krueger, N.F., Reilly, M.D., \& Carsrud, A.L. (2000). Competing models of entrepreneurial intentions. Journal of Business Venturing, 15(5/6), 411-432.

Kwong C., Jones-Evans, D., \& Thompson, P. (2012). Differences in perceptions of access to finance between potential male and female entrepreneurs: Evidence from the UK. International Journal of Entrepreneurial Behaviour \& Research, 18(1), 75-97.

Lim, D.S.K., Morse, E.A., Mitchell, R.K., \& Seawright, K. (2010). Institutional environment and entrepreneurial cognitions: A comparative business systems perspective. Entrepreneurship Theory and Practice, 34(3), 491-516.

Liñán, F., \& Chen, Y.W. (2009). Development and Cross-Cultural Application of a Specific Instrument to Measure Entrepreneurial intentions. Entrepreneurship Theory and Practice, 33(3), 593-617.

Lüthje, C., \& Franke, N. (2003). The 'making' of an entrepreneur. Testing a model of entrepreneurial intent among engineering students at MIT. $R$ \& D Management, 33(2), 135-47.

Pham, T.L. (2019). The Relationship between Perceived Access to Finance and Social Entrepreneurship Intentions among University Students in Vietnam. The Journal of Asian Finance, Economics and Business, 55(1), 63-72. 
Preacher, K.J., \& Hayes, A.F. (2008). Asymptotic and resampling strategies for assessing and comparing indirect effects in multiple mediator models. Behaviour Research Methods, 40, 879-891.

Robertson, M., Collins, A., Medeira, N., \& Slater, J. (2003). Barriers to start-up and their effect on aspirant entrepreneurs. Education \& Training, 45(6), 308-316.

Schwarz, E., Wdowiak, M., Almer-Jarz, D., \& Breitenecker, R. (2009). The Effects of Attitudes and Perceived Environment Conditions on Students Entrepreneurial Intent. Education + Training, 51(4), 272-291.

Sesen, H. (2013). Personality or environment? A comprehensive study on the entrepreneurial intentions of university students. Education + Training, 55(7), 624-640.

Shahid, M.S., Imran, Y., \& Shehryar, H. (2017). Determinants of entrepreneurial intentions: An institutional embeddedness perspective. Journal of Small Business \& Entrepreneurship, 30(2), 139-156.

Smith, K., \& Beasle, M. (2011). Graduate entrepreneurs: intentions, barriers and solutions. Education \& Training, 53(8/9), 722-740.

Turker, D., \& Selcuk, S.S. (2009). Which Factors Affect Entrepreneurial Intention of University Students?. Journal of European Industrial Training, 33(2), 142-159.

Urban, B., \& Ratsimanetrimanana, F.A. (2019). Access to finance and entrepreneurial intention. An empirical study of Madagascan rural areas. Journal of Enterprising Communities: People and Places in the Global Economy, 13(4), 455-471.

Verzat, C., \& Bachelet, R. (2006). Developing and Entrepreneurial Spirit among engineering college students: what are the educational factors?. In A. Fayolle, H. Klandt, \& E. Elgar (Eds.), Entrepreneurship education (pp. 191-217). Northampton, MA: Edward Elgar Publishing.

Wach, K., \& Wojciechowski, L. (2016). Entrepreneurial Intentions of Students in Poland in the View of Ajzen's Theory of Planned Behaviour. Entrepreneurial Business and Economics Review, 4(1), 83-94.

Yurtkorua, S.E., Kuşcub, Z.K., \& Doğanayc, A. (2014). Exploring the antecedents of entrepreneurial intention on Turkish university students. Procedia - Social and Behavioral Sciences, 150(2014), 841-850. 


\section{Author}

\section{Thu Thuy Nguyen}

Bachelor of Finance (National Economics University, Vietnam); Master of Business Administration (Boise State University, USA); PhD in Business and Management (National Economics University, Vietnam). Her research interests include entrepreneurship, migration, labour motivation, management.

Correspondence to: Thu Thuy Nguyen, PhD, Department of Business Management, National Economics University, 207 Giai Phong, Hanoi, Vietnam, e-mail: thuyntqtkd@neu.edu.vn ORCID (1) http://orcid.org/0000-0002-3973-607X

\section{Copyright and License}

(ㄷ) (1) $\Theta$

This article is published under the terms of the Creative Commons Attribution - NoDerivs (CC BY-ND 4.0) License http://creativecommons.org/licenses/by-nd/4.0/

\section{Published by the Centre for Strategic and International Entrepreneurship - Krakow, Poland}

The copyediting and proofreading of articles in English is financed in the framework 